\title{
Just when I needed you most: Establishing on-demand learning support in a regional university
}

\author{
Gail Wilson, Andrew McAuleya, Sally Ashton-Hay, Tina van Eyk \\ Southern Cross University, ${ }^{\mathrm{a}}$ Global Higher Education
}

\begin{abstract}
This article discusses the experiences and challenges of introducing a third-party learning support provider into the teaching and learning culture at Southern Cross University (SCU), a regional university with campus locations in New South Wales and Queensland. The provider was engaged to extend online study support after-hours to first year students to complement the on-campus and online academic skills consultations available during business hours. The case study covers a 2015 pilot, a wider roll-out in 2016, and finally, a 2017 university-wide access via the intranet as well as through nominated units. The project team collaborated, planned, and prepared for adding third-party student support with specific strategies used to implement institutional cultural change. The case study offers implications for practice and policy across the higher education sector through the lessons learned, including the need for a complementarity of services approach with existing student services, a team-based strategic approach with a provider representative, and the benefits from open and positive communication. The partnership between SCU and the third-party provider evolved to the mutual benefit of both organisations. Students received support and feedback when they needed it most, academic staff revitalised coursework, and the third-party provider fine-tuned a targeted service for the institution.
\end{abstract}

Implications for practice or policy:

- Situate the academic skills support services provided in-house and the service provided by the third-party provider as complementary to each other.

- Re-enforce this complementarity in all communication with students and academic staff.

- Adopt a team-based approach to planning the introduction and implementation of a thirdparty provider's services.

- Utilise the provider's strengths, such as data generation and reporting, that enable student usage information about the after-hours service to be disseminated across the university.

Keywords: student support, academic skills, third party provider, student retention, case study

\section{Introduction}

This article discusses the experiences and challenges of introducing a third-party learning support provider into a university's learning and teaching culture. The location of this initiative was Southern Cross University (SCU), a regional university with its main campus locations in New South Wales and Queensland. Like many regional universities, the issue of improving student retention and attainment was uppermost in the minds of senior management. This was justified as a matter of concern by a range of statistics including, for example, survey work published in the 2014 University Experience National Survey Report (Graduate Careers Australia \& The Social Research Centre, 2015) which showed that 288 of 1,285 students seriously considered leaving SCU in 2014. Partly as a response to this, and to other internal work being driven by the Student Engagement and Retention Team under the Pro-Vice Chancellor (Academic), the University in 2015 engaged the services of an online third-party provider (YourTutor as it was called, now Studiosity) to extend study support after-hours to primarily assist first year students. The third-party service focused on online foundational study support and general feedback support after-hours and on weekends to complement the on-campus and online academic skills consultations available during business hours. To introduce this complementarity of support and the potential of the third-party service to both students and academic staff, this service was provided initially to a small number of pilot units to assess the benefits. Studiosity's support is available in two types of services, both of which are measured in minutes consumed by a student:

- Connect Live: Synchronous tutorial service for online study support where students work with a tutor on a variety of subjects such as English Skills and Concepts, Accounting, Statistics and Study 
Skills. Support available Sunday to Friday (6 days), from 4pm to midnight.

- 24/7 Writing Feedback: Students upload their draft essay or assignment to the asynchronous 24/7 service for general feedback support focusing on spelling, grammar, punctuation, and structure with feedback returned within 24 hours.

In 2016, a project team consisting of university staff and the third-party's client consultant was established to expand the reach and take-up of the service across the university in primarily first year units, supported by senior teaching and learning school/college staff. Close to 100 units were nominated access. In late 2016, SCU held the first conference to unite university partners working with the third-party provider to openly discuss and share challenges and experiences to the benefit of all. In 2017, students were able to access the third-party provider service via the university intranet or nominated units. The partnership between SCU and Studiosity continued to evolve to support the learning needs of students until the end of 2019, when an alternative strategy was introduced in early 2020.

In this paper we explore the evolution of the partnership between SCU and Studiosity from its inception in 2015 to the end of 2017, a period when the authors of this paper worked together to establish and embed student use of the online service. The paper focuses on lessons learned which have benefitted both the learning and study support offered to students, and the work practices of both parties. The evidence for the success of the service is based on detailed data gained over an extended period of time from monthly reports and other data generated on a regular basis by Studiosity and analysed by the SCU team and distributed to schools/colleges. In addition, how the relationship was successfully managed to the benefit of all parties, including students, is a key part of our story. As such, this paper is an exemplar of the benefits to all parties of a collaborative-based approach involving a third-party provider when there is an openness and willingness to succeed, sometimes against the odds.

\section{Literature review - student retention}

The retention of students so that they can complete their course of study is a perennial challenge to universities and their staff, academic and professional (Beer \& Lawson, 2017; Kahu, 2013; Kahu \& Nelson, 2018; Tight, 2019). It is also an issue with far reaching implications for the Australian higher education sector where it poses significant risk for the sector's global reputation with knock-on effects to the financial sustainability of individual universities. Understandably, research has focused on students, but in the context of the delivery setting (face-to-face, online, blended); the academic and non-academic staff involved; as well as the policies and interventions designed to improve student outcomes. All this material contributes to the knowledge base which then influences the kinds of initiatives which take place in the area of retention (Bowles \& Brindle, 2017).

Although the focus on student retention may be thought to be recent, it has been a consideration for many years. Berger et al. (2012) trace discussion of student mortality, as it was termed, to the 1930s, but it was in the 1960s when the first systematic retention studies emerged. As the volume of students has increased over time and the delivery modes of education diversified, so too has the reported literature to address different retention contexts; for example, online retention (Simpson, 2003); college retention (Seidman, 2012); and higher education (Aljohani, 2016).

The influence of professional staff on student retention has also been studied, for example, in Roberts' (2018) study of library staff. With the growth of big data, the use of data analytics has also been documented (Colvin et al., 2016; Mah, 2016). Financial pressures on students are well known and have also been considered in relation to retention (Britt et al., 2017). In addition, pathways and the transition to university (Briggs et al., 2012; Leese, 2010;) and the impact of the first-year experience in improving retention has also received much attention (Krause \& Coates, 2008; Naylor et al., 2018; Picton et al., 2018; Wilcox et al., 2005). In more recent times, the growing awareness of mental health difficulties amongst university students has added a new dimension to the retention debate (Baik et al., 2019).

The focus on student retention is not based solely on achieving the social benefits a completed education provides, but indelibly linked to the level of public investment in that outcome and the political/economic interest in seeing a return on that investment (Dawkins et al, 2019; Tomlinson, 2018). Of course, the context is much more complicated as studies (Department of Education, Skills \& Employment, 2017) have shown that the measurement of completion over a longer time frame; for example, using a 9-year lens at regional 
universities leads to a similar percentage completion rate as the sector average. However, when the snapshot is an annual figure there is a much greater disparity. Even for those who do not complete university, there have been studies showing (Luckman \& Harvey, 2019; Schnepf, 2017) that even a limited exposure to higher education is beneficial.

In 2015, the official statistics from the Department of Education and Training (2016), (now the Department of Education, Skills and Employment) for SCU (noting that this was annualised 2014 data) showed overall retention for all commencing bachelor students to be $68.37 \%$. In relation to the entire sector, SCU was ranked 38 out of 40 universities. At that time the sector average was $80.6 \%$ (Department of Education, Skills and Employment, 2016). Additional national benchmarking in 2015 is provided by the Student Experience Survey whose results form part of the Commonwealth's Quality Indicators for Learning and Teaching (2016) public website indicators (now ComparED). The underpinning framework of this survey is based on six areas shown in Table 1, namely: skills development, learner engagement, teaching quality, student support, learning resources, and quality of educational experience (Graduate Careers Australia \& The Social Research Centre, 2015, p. iii).

Table 1

2015 sector- wide satisfaction with the student experience

\begin{tabular}{|l|r|r|r|r|r|r|}
\hline & $\begin{array}{c}\text { Skills } \\
\text { development }\end{array}$ & $\begin{array}{c}\text { Learner } \\
\text { engagement }\end{array}$ & $\begin{array}{c}\text { Teaching } \\
\text { quality }\end{array}$ & $\begin{array}{c}\text { Student } \\
\text { support }\end{array}$ & $\begin{array}{c}\text { Learning } \\
\text { resources }\end{array}$ & $\begin{array}{c}\text { Quality of } \\
\text { entire } \\
\text { educational } \\
\text { experience }\end{array}$ \\
\hline Commencing & 80 & 59 & 84 & 75 & 89 & 82 \\
\hline Later year & 84 & 62 & 78 & 68 & 81 & 76 \\
\hline Total & 81 & 60 & 82 & 72 & 86 & 80 \\
\hline
\end{tabular}

Summary figures from the SCU 2015 Student Experience Survey (2015, p. 3) are shown below in Table 2. While the figures mirror the entire higher education sector, they do illustrate that the areas of learner engagement and teaching quality are a concern. While the former is a standard issue across the tertiary sector, the SCU figure was 9 percentage points adrift of the sector. That said, the student support component was rated higher than the sector all together by the respondents. Overall, these figures do illustrate the complexity of engagement as a path to enhanced retention.

Table 2

Comparator figures for SCU 2015

\begin{tabular}{|l|r|r|r|r|r|r|}
\hline & $\begin{array}{c}\text { Skills } \\
\text { development }\end{array}$ & $\begin{array}{c}\text { Learner } \\
\text { engagement }\end{array}$ & $\begin{array}{c}\text { Teaching } \\
\text { quality }\end{array}$ & $\begin{array}{c}\text { Student } \\
\text { support }\end{array}$ & $\begin{array}{c}\text { Learning } \\
\text { resources }\end{array}$ & $\begin{array}{c}\text { Quality of } \\
\text { entire } \\
\text { educational } \\
\text { experience }\end{array}$ \\
\hline Total & 81 & 51 & 80 & 76 & 84 & 77 \\
\hline
\end{tabular}

While SCU shared many of the same characteristics in overall performance with the entire higher education sector, it did suffer from a poor performance rating in the area of retention. To explain this more, let us look at the SCU context in terms of its student cohort.

\section{Student cohort context}

In 2015, when SCU began its partnership with Studiosity, the student cohort context was one where the average age was 28 , with a student body more dominated by mature and female students studying at a distance with at least part-time employment being common. Overlay this with many equity groups being represented in the cohort, such as first-in-family, those from low socio-economic status backgrounds and a higher proportion of Aboriginal and Torres Strait Islander students, and the challenge around finding a retention magic bullet is that much harder. While the realists understand there is in fact no magic bullet, it does not stop the search for solutions to at least reduce attrition. Some factors the university has a degree of control over; for example, curriculum, delivery mode, assessment, and all the service processes surrounding student interaction with teaching and learning. In the case of other factors such as individual 
student finances, employment commitments, health (more commonly, mental health), and relationship issues, there is much less control.

That said, the responsibility to improve retention through appropriate strategies resided within the SCU Executive. These strategies were operationalised through the Student Retention and Engagement Team for engagement and student experience aspects, and through the Centre for Teaching and Learning for academic and student learning skills support. Both these areas acted in partnership across the University. This was an important philosophical point - that retention is everyone's responsibility regardless of position in the organisation. In addition, the Student Retention and Engagement Team had an important founding principle - that they were to have a disruptive mindset. Their brief was to innovate and try new initiatives. If they worked, good, keep doing them; if they had no impact, try something else. Resources were too constrained to keep doing everything if there was no apparent positive outcome. The Centre for Teaching and Learning had been recently reorganised and was very much in the mode of being responsive to academic and student needs and open to new initiatives.

In terms of student support within the Centre for Teaching and Learning, with an almost annual pressure on finances it became clear that re-imagining how services were delivered to students was a necessary part of any forward-thinking strategy. Increasingly it was recognised that the one-to-one model of academic skills assistance to students was inefficient in time, human resources and in dollars spent. At the same time, there was a desire and a challenge to enhance services by being clever about what was offered. It was within this context that the concept of working with a third-party provider, Studiosity, began to take shape.

\section{Case study}

Stake (1995) defined the case study as the object of study. This paper is a single, educational case study which tells the story of the establishment of after-hours learning support offered by Studiosity at SCU from 2015-2017. We draw upon a data record constructed for this 3 year period that included Studiosity reports prepared for SCU, our own reports we prepared for each teaching session that were distributed to schools/colleges, emails, and records of team meetings. The student voice in the narrative is taken from students' feedback about Studiosity's service that was captured from within the service interface each time a student completed a live tutorial session or after a student received email feedback on an assignment question. The case narrative is structured across a timeline (Table 3) that spans the piloting of the program in Session 1, 2015 through to the establishment of the program in 2016, and the widening of student access to the service throughout 2017. Institutional ethics approval was sought and received for this project (ECN16-158).

Table 3

Introduction of third-party provider learning support

\begin{tabular}{|l|l|l|}
\hline \multicolumn{1}{|c|}{2015} & \multicolumn{1}{|c|}{2016} & \multicolumn{1}{c|}{2017} \\
\hline Pilot Session 1 & Strategic, team-based approach \\
$\begin{array}{l}\text { Service trialled in 5 first year units: } \\
\text { health (2); business (2); education } \\
(1) .\end{array}$ & $\begin{array}{l}\text { Emphasis on complementarity of } \\
\text { academic services commenced. }\end{array}$ & $\begin{array}{l}\text { Widening access } \\
\text { Universal button established outside } \\
\text { of unit links to encourage student } \\
\text { access. }\end{array}$ \\
\hline Low access across 4 units. & $\begin{array}{l}\text { Multi-pronged approach to promote } \\
\text { university and third-party academic } \\
\text { services. }\end{array}$ & $\begin{array}{l}\text { Designated unit links continue } \\
\text { alongside Universal button for } \\
\text { greater access. }\end{array}$ \\
$\begin{array}{l}11 \% \text { usage in one unit with strong } \\
\text { teacher support. }\end{array}$ & $\begin{array}{l}\text { Many unit links established for } \\
\text { greater student access. }\end{array}$ & $\begin{array}{l}\text { Ongoing promotion of service } \\
\text { complementarity. }\end{array}$ \\
$\begin{array}{l}\text { Students who accessed the service } \\
\text { liked the service. }\end{array}$ & $\begin{array}{l}\text { School and college liaison and } \\
\text { regular reporting. }\end{array}$ & $\begin{array}{l}\text { Improvements from ongoing } \\
\text { collaboration. }\end{array}$ \\
\hline
\end{tabular}

\section{Stage 1: Pilot 2015}

Following exposure to Studiosity at a higher education sector conference and subsequent discussions it was agreed to implement a trial at SCU in Session 1, 2015. At the time of this trial, Studiosity offered synchronic academic support in basic academic skills, including literacy and numeracy between the hours of $3.00 \mathrm{pm}$ 
to midnight within the local time zone Sunday to Friday. This support included one-to-one consultation in a live (synchronous) online tutorial as well as asynchronous support via written feedback on assignments provided to students within 24 hours of assignment submission. Marketing and communication support strategies were provided by Studiosity for SCU to use to support the service. In-house Academic Skills support continued to operate during normal business hours.

The service was trialled in five SCU first year units with large student numbers to maximise the number of new first-year students given access. These units were CMM10580 (The Australian Health Care System), COM00207 (Communication in Organisations), MAT10251 (Statistical Analysis), MAT10002 (Mathematics and Numeracy), and BIO01302 (Human Anatomy). Access to the service was via each unit's Blackboard site, but also depended on the support of staff in Academic Skills and in the schools to drive awareness. A total of 102 students used the service across these units, a lower uptake than anticipated. One exception was the Business Communications unit where 60 students (around $11 \%$ of students in the unit) accessed the service. This unit was led by the one unit lecturer who was strongly committed to the trial. However, many of the 102 students accessed the service on more than one occasion. Support was provided on 301 occasions with contact for individual students ranging from 1 to 28 occasions of support. This suggests user satisfaction as students are returning to use the service again.

In terms of the total service minutes available for use, 6077 minutes (representing $27 \%$ of capacity) were used. This comprised 2312 minutes related to English and writing, 2700 minutes for essay review, 825 minutes for mathematics, 230 minutes for essential skills (i.e., research, library skills, and study skills), and 9 minutes for science. Table 4 below displays the total minutes consumed after the trial period of the Studiosity service, and at the end of the first year.

Table 4

2015 data comparison of third-party provider student usage end of trial period and end of year

\begin{tabular}{|l|r|}
\hline 2015 & Overall usage (minutes) \\
\hline $\begin{array}{l}\text { Trial period } \\
\text { Session 1: March to June }\end{array}$ \\
\hline Session 2: July to December & 6,034 \\
\hline
\end{tabular}

A sample of the student voice (in verbatim) from Studiosity datasets for 2015 Connect Live and Writing Feedback is provided below:

- I was feeling really overwhelmed with the essay, after speaking to the tutor $\mathrm{i}$ feel hopeful that $\mathrm{i}$ can turn this around :).

- $\quad$ F]irst session so i am excited about having questions answered immediately and having support along the way as this is my first year of study.

- Thank you so much, it is very comforting to know I'm on the right track with my writing style. Your tutor is quick and easy and there is no missing key points as its written down and I can review comments again and again.

- I find the feedback is excellent. Expert clearly pointed out my mistakes and provided me some examples, which I can rethink the structure of my assignment. Moreover, expert also remind me about the grammar and referencing problem which I need to pay attention to avoid the same mistakes in future. I appreciate for his/her help.

\section{Stage 22016}

Stage 2 aimed to promote awareness of the outsourced service and familiarise the SCU community with how Studiosity's services added value. Centre for Teaching and Learning staff - the Director, the Manager Academic Skills and the Project Officer met regularly with Studiosity's Queensland state representative to plan and enact a team-based approach. This approach adopted multi-pronged strategies: promoting the complementarity of the two academic support services; attending school/college board and staff meetings across SCU to deliver short presentations and respond to questions; and inviting unit lecturers to opt in to establish a connect button in their unit Blackboard learning sites. 
The complementarity of Academic Skills and Studiosity was emphasised through marketing, advertisements, posters, screen shots and social media with a focus on round-the-clock study support for students. High quality photos supplied by Studiosity were branded with Academic Skills and Studiosity to ensure the university community recognised the interrelatedness of the in-house business hours offered by Academic Skills and external after-hours services provided by Studiosity. The aim was to deliver an anytime, anywhere academic support service with the capacity to cover any study needs while also offering options.

From March to the end of May 2016, two team members attended each school/college board meeting as well as library, international office, and student services staff meetings to provide a 10 to 15 minute PowerPoint ${ }^{\mathrm{TM}}$ presentation and respond to questions. Table 5 highlights the round-the-clock complementarity of both services emphasised in the meetings. Studiosity's client manager prioritised trips from Brisbane to the Gold Coast and Lismore campuses for most of these meetings. By attending every school/college board and staff meeting across two campuses, the extended student support message was disseminated clearly. A total of 96 unit lecturers opted into the after-hours service by requesting the connect button be made available to students in their units.

Table 5

Extending academic support after-hours

\begin{tabular}{|c|c|c|}
\hline $\begin{array}{l}\text { SCU Academic Skills } \\
9.00 \mathrm{am} \text { to } 4.30 \mathrm{pm}\end{array}$ & $\begin{array}{c}\text { 24/7 Writing Feedback - } \\
\text { General Academic English } \\
\text { Studiosity }\end{array}$ & $\begin{array}{l}\text { 4pm to midnight } \\
\text { Connect Live Tutorials } \\
\text { Studiosity }\end{array}$ \\
\hline $\begin{array}{l}\text { - Unit-based assessments; } \\
\text { team teaching } \\
\text { - Workshops and Collaborate } \\
\text { sessions } \\
\text { - } \quad \text { Individual and small group } \\
\text { consultations } \\
\text { - Appointments face-to-face } \\
\text { on campus, phone/skype or } \\
\text { via online feedback } \\
\text { Development of academic } \\
\text { writing, referencing, } \\
\text { numeracy, critical thinking } \\
\text { and analysis, effective } \\
\text { reading, academic integrity, } \\
\text { academic literacy, PASS } \\
\text { and exam technique skills }\end{array}$ & $\begin{array}{l}\text { Focus on grammar, } \\
\text { punctuation, spelling, } \\
\text { structure } \\
\text { - } 24 / 7 \text { file upload } \\
\text { - } \quad \text { Any stage of the draft } \\
\text { process } \\
\text { - } \quad \text { Notification when feedback } \\
\text { is ready } \\
\text { - }\end{array}$ & $\begin{array}{ll}\text { - } & \text { Real-time study problems } \\
\text { - } & \text { Online } \\
\text { - } & \text { File sharing } \\
\text { - } & \text { Interactive whiteboard } \\
\text { - } & \text { One-to-one study support } \\
\text { for questions on foundation } \\
\text { knowledge and study skills } \\
\text { (statistics, economics, } \\
\text { bridging maths or science, } \\
\text { plus more) }\end{array}$ \\
\hline
\end{tabular}

From March to June 2016, 34,513 minutes were consumed by students, using 34\% of the capacity. The essay review service was used most frequently, and the average synchronous tutorial session was 23 minutes. The program was gaining momentum and culminated in the first Studiosity conference on October 27-28 hosted by SCU, attended by representatives of several universities who were using Studiosity or about to introduce the service. At the end of 2016, 60,009 minutes were consumed, using $60 \%$ of the capacity, a $39 \%$ increase when compared to usage in 2015. Table 6 below displays the number of Connect Live tutorial sessions, Writing Feedback submissions, and the total minutes consumed at the end of each teaching session. The minute usage amount over the year is cumulative.

Table 6

2016 data comparison of third-party provider student usage at end of month from start of year

\begin{tabular}{|l|c|c|c|}
\hline 2016 & $\begin{array}{c}\text { Connect Live } \\
\text { tutorial sessions }\end{array}$ & $\begin{array}{c}\text { Writing feedback } \\
\text { submissions }\end{array}$ & $\begin{array}{c}\text { Overall usage in } \\
\text { minutes }\end{array}$ \\
\hline End of Session 1 until 30 June & N/A & N/A & 34,513 \\
\hline End of Session 2 until 31 October & 324 & 568 & 55,016 \\
\hline End of year until 31 December & 377 & 725 & 60,009 \\
\hline
\end{tabular}


A sample of the student voice (in verbatim) from Studiosity datasets for 2016 Connect Live and Writing Feedback is provided below:

- $\quad$ W]hat an amazing offer this is, helps build confidence and lets us know we are doing ok. being a distance student $i$ am constantly worried $i$ am not correct with what $i$ am doing. This was so helpful.

- The review I received was very thorough and supportive. It was also returned to me very quickly (less than half an hour from when I submitted the file). This service is fantastic!

- My feedback was excellent. It was very specific about what I requested. I also appreciate how thorough it was and it has assisted me in the areas I usually have issues with. Thank you so much for the effort you put into helping me better my work.

- Thank you for the feedback. It will help me a lot! Your feedback is great, and easy to understand for a international student. Thank you and keep up the good work!

During Stage 2 it became apparent from our SCU reports that students were accessing Studiosity's services using an access button in units in which they were not enrolled. In other words, they may have been using a friend's access to gain feedback on their own work for a different unit that did not have an access button. Another issue that arose during this stage was the confusion with the name YourTutor. When an Academic Skills staff asked a student whether they had accessed YourTutor, the student invariably responded, "he wasn't in his office" or "she hasn't answered my email yet". Students also mixed up the name calling the service My Tutor which seemed to be students referring to their lecturers and not the provider's service. This issue disappeared when the provider changed their name to Studiosity.

\section{Stage 32017}

The data from this stage demonstrates the successful uptake of the third-party provider service. A universal button had been added to all units and students could access the service from the Blackboard learning site or through a MySCU page with Academic Skills and Studiosity. As the management team for this project we continued to meet regularly, but discussions revolved more around troubleshooting issues and managing the contract capacity. We realised that the consumption was outstripping the capacity with essay reviews the most accessed service. Table 7 displays the number of Connect Live tutorial sessions, Writing Feedback submissions, and the total minutes consumed at the end of each session. In this table the figures for Session 1, 2017 Connect Live and Writing Feedback services combined both sessions and minutes as a total figure. Based on feedback from SCU and other universities, Studiosity improved the reporting details to separate the minutes for each service from Session 2, 2017. This change is reflected in Table 7. The level of reporting detail available to SCU from Studiosity continued to improve over time based on suggestions from the SCU project team.

Table 7

2017 data comparison of third-party provider student usage at end of month from start of year

\begin{tabular}{|l|r|r|r|}
\hline 2017 & $\begin{array}{c}\text { Connect Live tutorial } \\
\text { sessions and minutes } \\
\text { in brackets }\end{array}$ & $\begin{array}{c}\text { Writing Feedback } \\
\text { submissions and } \\
\text { minutes in brackets }\end{array}$ & $\begin{array}{c}\text { Overall usage } \\
\text { in minutes }\end{array}$ \\
\hline End of Session 1 until 30 June & 377 & 1,163 & 44,611 \\
\hline End of Session 2 until 31 October & $624(12,160)$ & $2,331(62,505)$ & 74,665 \\
\hline End of year until 31 December & $642(12,448)$ & $2,518(67,630)$ & 80,078 \\
\hline
\end{tabular}

At the end of December 2017, total minutes consumed were 80,078, where capacity was at $98 \%$. The breakdown between Connect Live tutorials and Writing Feedback submissions shows 642 live tutorial sessions using 12,448 minutes, and 2,518 submissions for essay feedback consuming 67,630 minutes. The most popular times of access were from $4 \mathrm{pm}$ to $6 \mathrm{pm}$. 
A sample of the student voice (in verbatim) from Studiosity datasets for 2017 Connect Live and Writing Feedback is provided below:

- This session went very well, I felt no pressure from the tutor and she guided me to find a solution and really explain the context.

- Direction and clarity with regard to corrections that had to be made was gained through relevant and concise feedback. Thank you.

- Offered good advice and reminded me some hints that I had forgotten about. Helped boost my confidence. Thank You!

- This feedback was incredible. Since English is not my first language, I appreciate this help so much. Very constructive feedback with good comments yet encouraging. Thank you!

In Stage 3, some differentiation of the services took place after student feedback. Academic Skills was marketed as unit-based academic support while Studiosity was branded as generic support. Several videos were made and uploaded to the SCU website with students and staff discussing the benefits of both services. International students talked about how they used both services purposefully and productively. Marketing for both in-house academic support and the external provider's services included social media, SCU media screens, and all-student emails.

\section{Challenges}

One challenge we met in rolling out a third-party provider online academic support service was acceptance of an external third-party provider in the prevailing institutional culture. Dickson et al. (2017, p. 106) claim that university efforts to increase support and implement quality assurance are disjointed due to a key impediment of universities' organisational cultures, "which often attach little value to learning and teaching". Similarly, our staff were accustomed to the status quo and reticent about endorsing an unfamiliar after-hours online academic support provider. Some schools/colleges had concerns about the quality of academic advice delivered to students, who was going to provide this advice, and how accurate it would be, particularly in relation to specific discipline content. There was also staff anxiety about external providers moving into their discipline territory, coupled with a wider potential for imminent redundancy or job loss providing further reasons for concern.

Our team working on the introduction of this service to SCU acutely recognised that the resistance to such a third-party service required targeted marketing strategies. Stage 2 of the project described above indicated a focus on information sharing and discussion across SCU. Our emphasis was on the complementarity of the two services - internal and external - in digital signage, social media postings, first year students' diaries, and posters advertising both types of academic support services across SCU campuses.

The climate began to change slowly with the broad realisation that Studiosity was partnering with other universities to make an impact in supporting students. As indicated earlier, more and more unit lecturers opted to have a Studiosity hyperlink placed in their online unit learning site until staff started asking why the link was not in their unit. At that point, a universal hyperlink button established mainstream access for students from SCU's web page. This increased demand marked a turning point in cultural acceptance and uptake across the University.

A second challenge we faced arose from Studiosity feedback provided to students on their draft written assignment. With the likely intention of encouragement, some feedback was overly positive with phrases such as "excellent essay", "very well written" and "great work!" The essay might be written well, but if the content does not respond to the assignment task and marking criteria effectively, the result could be disappointing. Several international students received rosy feedback and assumed they would succeed in relation to the assignment, but unfortunately failed because they had not answered the question. These cases were taken by the team to the third-party provider. Institutions need to "work in deep collaboration with their contractors to achieve the desired economies of scale" (Wekullo, 2017, p. 466), and incidents like this demonstrate the harm caused to students and to the institution if misleading advice is given. The situation was ultimately resolved through a complete overhaul and revision of the Studiosity feedback system, an acceptable resolution to avoid such issues recurring in the future. 
A third challenge that arose involved a student with a learning disability. The student used Studiosity nine times to improve on a written draft for an assignment. The assignment failed to meet the standards required and the student informed the school how much effort had gone into this work. Each time the student had gone to Studiosity a different tutor had given different advice, and there was a lack of developmental consistency. When we met as a management team to discuss this challenge, we concluded that a student with a learning disability would benefit more from working with the same Academic Skills advisor instead of randomly available tutors with Studiosity. The advice provided by Studiosity tutors was reported back to the company for further action.

Studiosity met each of the challenges discussed above with responsiveness and a commitment to fine-tune the effectiveness of the overall service in order to better meet the needs of the University. The working relationship between the SCU and Studiosity was productive and positive.

\section{Lessons learned}

From the very beginning of the introduction of Studiosity as a third-party provider our team constantly engaged in communication, listening and responding. We learned to adapt to different situations as they arose. Our solutions drew upon our capacity to remain flexible and to communicate clearly with each other about issues. The project clearly pushed us in the direction of differentiation of the services provided in relation to student learning support -general essay feedback from the third-party provider and unit-based feedback with review of marking criteria and assignment questions from their in-house Academic Skills staff. We provided statistics to schools/college about their students' use of Studiosity's services, took complaints on board quickly and presented information back to Studiosity for action, all designed to improve the service being offered by the provider but also to celebrate and highlight the complementarity of both services.

We also managed our own Academic Skills' staff concerns that arose from time to time and concerns from some academics that saw the introduction of a third-party provider service as a threat to traditional practice. The entire process of introducing and implementing this service was disruptive - by that we mean it challenged traditional ways of providing a service and was seen by some as a "Trojan Horse" that would lead to outsourcing of functions like Academic Skills. This was never the intention of the project, nor was it something that happened.

As a project team we believed in strong relationship management between the team and Studiosity. We troubleshooted problems and sought solutions. Studiosity was responsive to our requests for information. They shared data they collected about student usage of their services and we were able to benefit from the advanced technologies they employed to track student use of the service which improved the functionality of the systems they provided for all Studiosity clients.

Regarding the impact of the introduction of an after-hours service on student retention at SCU, without the ability to have a strict control group within the initiative it is impossible to show undisputed cause and effect. In addition, there were several projects running at the time aimed at improving the student experience, one of which was Studiosity. However, we know anecdotally from staff interaction with students that the initiative made a difference to individual students and their study outcomes. More systematically, the latest Department of Education, Skills and Employment (2019) statistics provided in Table 8 are additional evidence of improvement over the first three years of the initiative. Note that the calculation of the retention rate was adjusted to "New Normal Attrition Rate" from 2016.

Table 8

Time series New Normal Attrition for SCU 2014-2017

\begin{tabular}{|l|c|c|c|c|}
\hline Year & 2014 & 2015 & 2016 & 2017 \\
\hline Total & 70.02 & 72.20 & 70.07 & 66.37 \\
\hline
\end{tabular}

The starting figure for SCU in 2014 was $68.37 \%$ which is now being reported as $70.02 \%$. That said, the time series does show that from 2015 when the Studiosity service was introduced, the attrition rate was reduced in successive years to $66.37 \%$ in 2017 , a reduction of $3.65 \%$. This improvement in student outcomes is testimony to the successful partnership established with Studiosity and the willingness of the team at SCU to embrace a new way of operating. 


\section{Further research}

As a team we can identify several areas for further research that could build on the work of this project. The first of these is an examination of the key components of the relationship between the student and the tripartite links to Studiosity, university support and peer support. Preference, roles and prevalence could be explored as to how the user navigates this network of support. Secondly, as student success is a key driver of partnerships with third party providers, then a large data set approach would be to use the student data management framework within the university to establish the impact on completion. While cause and effect would be complex, it is envisaged that with the use of mixed methodologies insights would be gained with policy implications. Thirdly, we suggest closing the loop on assessment by feeding back to schools/faculties information about specific assessment tasks that students struggled with and sought help for from Studiosity. There is also the potential to use this same feedback to devise more targeted curriculum support through embedding academic skills and/or designing workshops to enhance threshold concepts, liminal spaces and troublesome knowledge (Meyer \& Land, 2005).

\section{Conclusion}

For many years the higher education sector has been the focus of private providers whose business model is essentially to offer services in a leaner and more efficient way than the university while at the same time increasing the perception of student quality and overall satisfaction. This approach often meets internal resistance from staff across the institution whether academic or professional. That said, perhaps the pragmatic response is to accept that these providers are here to stay, and we can either ignore them and watch them erode our markets, or we can partner with them and look to turn the relationship to the advantage of all parties, including students.

\section{Acknowledgements}

Ms Nicole Seipel, Partnership Services Manager, Studiosity Queensland; nseipel@studiosity.com

\section{References}

Aljohani, O. (2016). A comprehensive review of the major studies and theoretical models of student retention in higher education. Higher Education Studies, 6(2), 1-18. https://doi.org/10.5539/hes.v6n2p1

Baik, C., Larcombe, W., \& Brooker, A. (2019). How universities can enhance student mental wellbeing: The student perspective. Higher Education Research \& Development, 38(4), 674-687. https://doi.org/10.1080/07294360.2019.1576596

Beer, C., \& Lawson, C. (2017). The problem of student attrition in higher education: An alternative perspective. Journal of Further and Higher Education, 41(6), 773-784. https://doi.org/10.1080/0309877X.2016.1177171

Berger, J. B., Ramirez, G. R., \& Lyons, S. (2012). Past to present: A historical look at retention. In A. Seidman (Ed.), College student retention: Formula for student success (2nd ed., pp. 7-34). Rowman $\&$ Littlefield.

Bowles, T. V., \& Brindle, K. A. (2017). Identifying facilitating factors and barriers to improving student retention rates in tertiary teaching courses: A systematic review. Higher Education Research \& Development, 36(5), 903-919. https://doi.org/10.1080/07294360.2016.1264927

Briggs, A. R. J., Clark, J., \& Hall, I. (2012). Building bridges: Understanding student transition to university. Quality in Higher Education, 18(1), 3-21. https://doi.org/10.1080/13538322.2011.614468

Britt, S. L., Ammerman, D. A., Barrett, S. F., \& Jones, S. (2017). Student loans, financial stress, and college student retention. Journal of Student Financial Aid, (47)1, 25-37. https://ir.library.louisville.edu/jsfa/vol47/iss1/3

Colvin, C., Rogers, T., Wade, A., Dawson, S., Gasevic, D., Buckingham Shum, S., Nelson, K., Alexander, S., Lockyer, L., Kennedy, G., Corrin, L., \& Fisher, J. (2016). Student retention and learning analytics: A snapshot of Australian practices and a framework for advancement. Canberra. http://hdl.handle.net/10453/117173 
Dawkins, P., Hurley, P., \& Noonan, P. (2019). Rethinking and revitalising tertiary education in Australia. Melbourne. http://www.mitchellinstitute.org.au/wp-content/uploads/2019/05/Rethinking-andrevitalising-tertiary-education-FINAL.pdf

Department of Education, Skills and Employment (2016). Appendix 4 - Attrition, success and retention. Canberra. https://docs.education.gov.au/documents/2016-appendix-4-attrition-success-and-retention

Department of Education, Skills and Employment (2017). Higher education standards panel final report - Improving retention, completion and success in higher education. Canberra. https://docs.education.gov.au/node/50816

Department of Education, Skills and Employment (2019). 2018 Section 15 Attrition, success and retention. Canberra. https://docs.education.gov.au/node/53029

Dickson, K., Hughes, K., \& Stephens, B. (2017). Outsourcing academic development in higher education: Staff perceptions of an international program. International Journal for Academic Development, 22(2), 106-119. https://doi.org/10.1080/1360144X.2016.1218884

Graduate Careers Australia \& The Social Research Centre (2015). 2014 university experience survey national report. https://www.qilt.edu.au/docs/default-source/ues-national-report/2014-universityexperience-survey-national-report/ues 14 report final access2a.pdf?sfvrsn=8061e13c 4

Kahu, E. (2013). Framing student engagement in higher education. Studies in Higher Education, 38(5), 758-773. https://doi.org/10.1080/03075079.2011.598505

Kahu, E., \& Nelson, K. (2018). Student engagement in the educational interface: Understanding the mechanisms of student success. Higher Education Research \& Development, 37(1), 58-71. https://doi.org/10.1080/07294360.2017.1344197

Krause, K., \& Coates, H. (2008). Students' engagement in first-year university. Assessment \& Evaluation in Higher Education, 33(5), 493-505. https://doi.org/10.1080/02602930701698892

Leese, M. (2010). Bridging the gap: Supporting student transitions into higher education. Journal of Further and Higher Education, 34(2), 239-251. https://doi.org/10.1080/03098771003695494

Luckman, M., \& Harvey, A. (2019). The financial and educational outcomes of bachelor's degree noncompleters. Journal of Higher Education Policy and Management, 41(1), 3-17. https://doi.org/10.1080/1360080X.2018.1553106

Mah, D. (2016). Learning analytics and digital badges: Potential impact on student retention in higher education. Technology, Knowledge and Learning, 21(1), 285-305. https://doi.org/10.1007/s10758016-9286-8

Meyer, J. H. F., \& Land, R. (2005). Threshold concepts and troublesome knowledge (2): Epistemological considerations and a conceptual framework for teaching and learning. Higher Education 49(3), 255289. https://doi.org/10.1007/s10734-004-6779-5

Naylor, R., Baik, C., \& Arkoudis, S. (2018). Identifying attrition risk based on the first year experience. Higher Education Research \& Development, 37(2), 328-342. https://doi.org/10.1080/07294360.2017.1370438

Picton, C., Kahu, E., \& Nelson, K. (2018). Hardworking, determined and happy: First-year students' understanding and experience of success. Higher Education Research \& Development, 37(6), 12601273. https://doi.org/10.1080/07294360.2018.1478803

Quality Indicators for Learning and Teaching (2016). 2015 student experience survey national report. https://www.qilt.edu.au/docs/default-source/default-document-library/2015-student-experiencesurvey-national-report09208891b1e86477b58fff00006709da.pdf?sfvrsn=4dc8ec3c 0

Roberts, J. (2018). Professional staff contributions to student retention and success in higher education. Journal of Higher Education Policy and Management, 40(2), 140-153. https://doi.org/10.1080/1360080X.2018.1428409

Schnepf, S. (2017). How do tertiary dropouts fare in the labour market? A comparison between EU countries. Higher Education Quarterly, 71(1), 75-96. https://doi.org/10.1111/hequ.12112

Seidman, A. (2012). College student retention: Formula for student success (2nd ed.). Rowman \& Littlefield.

Simpson, O. (2003). Student retention in online open and distance learning. Routledge.

Southern Cross University (2015). 2015 student experience survey. SCU summary report. SCU Office of Planning, Quality and Review. https://www.scu.edu.au/staff/planning-quality-and-review/studentfeedback/student-experience-survey/

Stake, R. (1995). The art of case study research. Sage Publications.

Tight, M. (2019). Student retention and engagement in higher education. Journal of Further and Higher Education, 44(5), 698-704. https://doi.org/10.1080/0309877X.2019.1576860 
Tomlinson, M. (2018). Conceptions of the value of higher education in a measured market. Higher Education 75(4), 711-727. https://doi.org/10.1007/s10734-017-0165-6

Wekullo, C. (2017). Outsourcing in higher education: The known and unknown about the practice. Journal of Higher Education Policy and Management, 39(4), 453-468. https://doi.org/10.1080/1360080X.2017.1330805

Wilcox, P., Winn, S., \& Fyvie-Gauld, M. (2005). It was nothing to do with the university, it was just the people: The role of social support in the first-year experience of higher education. Studies in Higher Education, 30(6), 707-722. https://doi.org/10.1080/03075070500340036

\section{Corresponding author: Gail Wilson gail.wilson@scu.edu.au}

Copyright: Articles published in the Australasian Journal of Educational Technology (AJET) are available under Creative Commons Attribution Non-Commercial No Derivatives Licence (CC BY-NCND 4.0). Authors retain copyright in their work and grant AJET right of first publication under CC BYNC-ND 4.0.

Please cite as: Wilson, G., McAuley, A., Ashton-Hay, S., \& van Eyk, T. (2021). Just when I needed you most: Establishing on-demand learning support in a regional university. Australasian Journal of Educational Technology, 36(5), p-pp. https://doi.org/10.14742/ajet.6117 